\title{
The Mexican Judiciary's Understanding of the Corporate Responsibility to Respect Human Rights
}

\author{
Humberto CANTÚ RIVERA*
}

Keywords: case law, corporate responsibility to protect human rights, human rights policy, Mexico, UN Guiding Principles on Business and Human Rights

\section{INTRODUCTION}

The Latin American region has taken relatively slow steps to develop a regional agenda on business and human rights. ${ }^{1}$ It was only in January 2015 that the first meeting on the topic was convened at the Organization of American States. Some states have nevertheless been active in this field: Colombia has developed several initiatives on this issue, led by the Government or civil society; Chile recently started developing a national business and human rights plan, the first in Latin America. Argentina and Guatemala have also announced their intention to develop domestic policies to implement the UN Guiding Principles.

Mexico, an economically and politically powerful state in the region, has been noticeably absent. Despite its status as a member state of the OECD and its support in 2011 to the resolution whereby the United Nations (UN) Human Rights Council endorsed the Guiding Principles on Business and Human Rights (UN GPs), Mexico has taken few steps to develop a national business and human rights strategy or action plan. It is particularly surprising given the country's position as one of the top ten FDI host economies in the world. ${ }^{2}$ Nevertheless, despite the current reticence on how to approach the question of business and human rights policy-wise, the judicial system of Mexico (and particularly its Supreme Court) has recently resolved some cases that clearly

\footnotetext{
* Associate Researcher and PhD Candidate for the Centre de recherche sur les droits de l'homme et le droit humanitaire (CRDH) of Université Panthéon-Assas Paris II. Expert Adviser to the Delegation of Mexico for the First session of the Open-Ended Intergovernmental Working Group on transnational corporations and other business enterprises with respect to human rights.

1 See, e.g., Emilio Godoy, 'Lip-Service But Little Action on UN Business and Human Rights Principles in Latin America', Inter Press Service (21 March 2015), http://www.ipsnews.net/2015/03/lip-service-but-little-action-on-u-nbusiness-and-human-rights-principles-in-latin-america/ (accessed 13 August 2015).

2 United Nations Conference on Trade and Development, World Investment Report 2014: Overview (New York/ Geneva: UN, 2014) 4, 14.
} 
demonstrate the belief that corporations at least have a responsibility to respect human rights, either as a result of societal expectations or as a result of their position in society.

This note will briefly address the small preliminary steps that have been taken in domestic policy and case law, and will reflect upon possible ways forward for this topic in the country.

\section{Business and Human Rights in the Domestic and Foreign POLICIES OF MEXICO}

Human rights policy in Mexico is co-ordinated through the National Human Rights Programme 2014-2018, a national strategy in force since 30 April 2014, ${ }^{3}$ which has included for the first time a section devoted to human rights in the private sphere. The fourth objective of the Programme recognizes that to ensure and strengthen human rights protection, it is necessary to regulate the actions of private actors and to promote the development of a human rights culture in corporations or private institutions. ${ }^{4}$

To achieve this, the Programme has established five action lines in its Strategy 4.4: (i) strengthening the mechanisms in charge of ensuring respect of human rights by corporations and the private sector; (ii) promoting that companies disseminate human rights standards and include them in their statements of principles, codes of ethics, and policies; (iii) promoting a human rights approach in corporate social responsibility; (iv) fostering that legislation that aims to regulate corporations ensures respect of human rights; and (v) collaborating with companies to raise awareness of their human rights obligations regarding their employees and customers. ${ }^{5}$ Thus, it includes several of the policy recommendations made by the former UN Special Representative on Business and Human Rights, particularly in relation to the development of corporate human rights policies and of the state duty to protect through regulation and legislation.

Additionally, the foreign policy of Mexico in relation to business and human rights has supported the internationalization of business and human rights standards in line with the UN GPs and the OECD Guidelines for Multinational Corporations, both at the universal and regional level. ${ }^{6}$ However, despite the country's position in multilateral organizations, the issue has not transcended the several ministries in charge of overseeing the different aspects covered by the UNGPs at the domestic level. ${ }^{7}$ The National Human Rights Commission has not yet taken any type of action in relation to the UN GPs. ${ }^{8}$

\footnotetext{
3 Diario Oficial de la Federación, Programa Nacional de Derechos Humanos 2014-2018 (México, Distrito Federal: Secretaría de Gobernación 30 April 2014).

4 Ibid, 98.

5 Ibid, 99.

6 Committee on Juridical and Political Affairs, Organization of American States, 'Special Meeting on Promotion and Protection of Human Rights in Business', CP/CAJP/SA-560/15 (6 February 2015).

7 A request for access to information directed to the Ministries of Foreign Affairs, of the Interior, and of Economy by the author revealed that only the latter had taken some preliminary steps to disseminate the Guiding Principles and the OECD Guidelines at the domestic level, mainly through its OECD National Contact Point. Resolutions of requests of access to information on file with the author.

8 A request for access to information on file with the author revealed that no projects or actions were being undertaken by the NHRI of Mexico as of January 2015. However, an interesting and groundbreaking recommendation issued by the Human Rights Commission of Nuevo Leon (a state human rights commission) addressed for the first time the issue of business and human rights in the context of a NHRI in Mexico. Due to space limitations, it will not be commented on
} 
This potentially shows that, despite the actions of Mexico in the international arena, a lack of policy coherence and co-ordination has been an important obstacle for the adoption of a business and human rights strategy in the country. Expectations on this issue as a matter of public policy are high, particularly taking into consideration the recent reforms to the energy and telecommunications sectors, which may allow an significant number of multinational corporations to enter the Mexican market. The lack of effective regulation ${ }^{9}$ and legislation with a human rights approach, as well as of a national strategy on business and human rights, could pose important challenges to the protection of human rights in Mexico in the face of corporate activity.

\section{Relevant Case Law Dealing with Business and Human RIGHTS}

While the public policy of Mexico has not been instrumental in ensuring that the UN GPs are appropriately disseminated and implemented throughout the country, the work of the Mexican judiciary has been particularly groundbreaking. ${ }^{10}$ Two recent cases ${ }^{11}$ reviewed by the Mexican Supreme Court dealt with the obligation of companies to respect and comply with human rights norms.

In the first case, two plaintiffs brought an amparo $^{12}$ claim against a judicial decision in a civil case absolving a real estate development company from nullifying a purchase agreement and paying compensation for its non-compliance with the human right to adequate housing. In the civil claim and its subsequent appeals, the main argument was that the company failed to respect the specific requirements of the human right to an adequate standard of living, and in particular its housing dimension, developed in Article 11.1 of the International Covenant on Economic, Social and Cultural Rights, as well as

(F'note continued)

here. For further details see Comisión Estatal de Derechos Humanos de Nuevo León, 'Casino Royale', Recommendation 103/2012 (31 December 2012); see also Humberto Cantú Rivera, 'Transitional Justice, Human Rights and the Restoration of Credibility: Reconstructing Mexico's Social Fabric' (2014) 7(1) Mexican Law Review 57, $72-75$.

9 An interesting case study is that of the Buena Vista Copper Mine owned by Grupo Mexico, in the north-eastern state of Sonora, where a leak of toxic waste polluted the waterways used by several peasants, farmers, and the rural population, prejudicing their livelihoods and their human rights to water, health, and, ultimately, to live a life in dignity. The Government imposed sanctions worth close to $\$ 1.5$ million dollars, and the company established a compensation fund of approximately $\$ 131$ million dollars to repair the damages; however, it has not reached the most affected victims. See the case and company profiles in Business and Human Rights Resource Centre, 'Grupo México', http://businesshumanrights.org/en/grupo-méxico (accessed 13 August 2015).

10 The Supreme Court adopted in 2014 an Action Protocol for Judges on Cases Related to Development and Infrastructure Projects, in order to standardize judicial practice in such cases, see http://www.sitios.scjn.gob.mx/ ProtocoloMegaproyectosSCJN.pdf (accessed 25 July 2015).

11 Several other cases are currently being reviewed by local and federal courts, mostly in relation to the activities of mining companies; however, few judicial decisions have been passed so far.

12 The amparo procedure is used, among others, to challenge the conformity of a judgment with constitutional provisions, normally before the federal courts. An amparo directo en revisión is a procedure whereby the Supreme Court may exceptionally and discretionally attract a case for review where the direct interpretation of a constitutional provision or human right is the subject matter. It is a constitutional procedure originating in the 1850s under Mexican constitutional law, which was later adopted by other Latin-American jurisdictions and by Spain. For a recent review of the amparo procedure under Mexican law, that also considers the important constitutional reforms of 2011 on this instrument, see Eduardo Ferrer Mac-Gregor and Rubén Sánchez Gil, 'El amparo mexicano del siglo XXI: Notas sobre su nuevo régimen constitucional y legal' (2013) Anuario de Derecho Constitucional Latinoamericano 165. 
through General Comment No. 4 by the UN Committee on Economic, Social and Cultural Rights, ${ }^{13}$ giving rise to a human rights violation that would nullify the contract.

In its analysis of the claim, the Supreme Court stated that the obligation to implement adequate measures to comply with international and national human rights standards extended to the private sector participating in the development of real estate, and was not exclusive to state organs. ${ }^{14}$ Furthermore, the Supreme Court based its argument of human rights compliance by non-state actors on the 'basic expectation of society that corporations will abide by the applicable standards'. ${ }^{15}$ The Court also made reference to the state duty to protect people from human rights violations by corporations, and to the latter's responsibility to respect human rights, ${ }^{16}$ while pointing out that compliance with human rights was not subject to the will of the parties as a result of being a public policy exception. ${ }^{17}$ Thus, while not directly quoting the standards developed by the UN Special Representative on Business and Human Rights, the Supreme Court acknowledged that such basic social expectations on corporate conduct would require them to comply with the law and to respect human rights. ${ }^{18}$

Mexican domestic law was changed significantly in 2013 when a new Amparo Act was passed by Congress, according to which a private person would be deemed as a 'responsible authority whenever it performs acts equivalent to those of an authority, that affect rights as understood in this section, and whose functions are determined by a general norm'. ${ }^{19}$ In this sense, the Amparo Act states that any legal person that through its actions or omissions affects the rights of a third party can be considered a responsible authority, and thus subject to an amparo proceeding, to stop an irreparable damage to a human right that may be affected by its actions.

A second case reviewed by the Mexican Supreme Court, which follows this line of thought, was a complaint appeal (recurso de queja ${ }^{20}$ filed in an amparo claim in which an indigenous community (the Hñähñu) brought a complaint against Telmex (the leading information and communications technology (ICT) service provider in the country) and the Ministry of Communications and Transport, for the alleged violation of the rights to freedom of expression, access to information, equality before the law, and the right to work, ${ }^{21}$ as determined by the American Convention on Human Rights and its Additional Protocol. The plaintiffs argued that the company had failed to ensure the continuous and

\footnotetext{
13 Committee on Economic, Social and Cultural Rights, 'General Comment No. 4: The Right to Adequate Housing (Art 11(1) of the Covenant)', E/1992/23 (1 January 1992).

14 Judgment, Amparo Directo en Revisión No. 3516/2013 (First Chamber of the Supreme Court, 22 January 2014), 49-50.

15 Ibid, 53.

16 Ibid, 37.

17 Ibid, 54.

18 Curiously, this position has been criticized by human rights scholars, who see it as not providing enough basis for the legalization of a human rights standard applicable to corporations; see generally Surya Deva and David Bilchitz (eds.), Human Rights Obligations of Business: Beyond the Corporate Responsibility to Respect? (Cambridge: Cambridge University Press, 2013). This case, while an isolated example, reflects how it may not necessarily be a baseless provision.

19 Ley de Amparo 2013 (Mexico), Art 5 fr. II.

20 A recurso de queja is an appeal available to the parties of an amparo trial, whereby the party that was affected by the decision of the court to review an amparo can file an appeal on the basis that-inter alia-the decision was inappropriate.

21 Judgment, Recurso de Queja No. 23/2014 (Second Chamber of the Supreme Court, 26 March 2014).
} 
permanent provision of the telephone and internet services, while the state had failed to protect and ensure their human rights due to a lack of diligent supervision on the provision of the telecommunications services that were licensed to the private corporation.

The Court took note of the allegations by the plaintiffs stating that, as the company was in charge of the telecommunications public service (deemed a strategic field by the Constitution, which could be licensed to private companies), it could not abruptly interrupt the service provision: that action would affect the right to an adequate standard of living, unless a constitutional exception explicitly allowed it. ${ }^{22}$ Furthermore, it highlighted the argument of the plaintiffs that the case law of the Inter-American Court of Human Rights has enshrined the role that telecommunications have within a democracy for the exercise of the right to freedom of opinion and expression.

Through the complaint appeal submitted to the Supreme Court, Telmex fought the decision of a District Court, which allowed the lawsuit to proceed and deemed it a 'responsible authority'. However, the Supreme Court dismissed the appeal filed by the company on the basis that it would be necessary to confront facts and evidence submitted by the parties during the trial stage to evaluate whether the actions or omissions attributed to Telmex constitute an 'act of authority' capable of infringing upon the human rights of the Hñähñü. ${ }^{23}$

In the first instance, ${ }^{24}$ the District Court hearing the amparo claim determined that the company had unilaterally suspended the service provision to some of the plaintiffs (translating therefore into a violation of their human rights, which would have entailed a reparation of the inflicted damages), and that the state had failed to protect the human rights of the Hñähñü by not appropriately overseeing the activities of the corporation. ${ }^{25}$ Nevertheless, as a result of the reinstatement of the service by the company during the proceedings, the court dismissed the claim.

However, it is particularly relevant that the District Court decided not to analyse whether Telmex could be considered a 'responsible authority' in the case, ${ }^{26}$ even more so due to the fact that the review filed by the plaintiffs and by one of the state authorities against the judgment of the District Court rests precisely on that aspect. The Collegiate Tribunal hearing the review, however, transferred the case to the Supreme Court, asking it to determine (i) the scope of Article 5-II of the Amparo Act (whereby a non-state actor may be deemed as a responsible authority), (ii) to set forth the criterion to be applied to determine whether an amparo claim may proceed in cases where the acts of private entities have negative impacts upon human rights, and (iii) to determine if private parties providing public services can violate the human rights of their stakeholders, and thus if such actions are susceptible of being claimed through an amparo lawsuit. ${ }^{27}$ While still

22 Ibid, 11.

23 Ibid, 16-17.

24 Judgment, Matilde Reyes Esteban et al v Telmex, S.A.B. de C.V. et al, Juicio de Amparo No. 68/2014 (Second District Court for Administrative Matters, Specialized in Antitrust, Broadcasting and Communications, 15 December 2014) $46,50$.

25 Ibid, 40-41.

26 Ibid, 56.

27 Judgment, Amparo Review No. 19/2015 (First Circuit Collegiate Tribunal for Administrative Matters, Specializing in Antitrust, Broadcasting and Communications, 2 July 2015) 16-17. 
under consideration, there is a high probability that the Mexican Supreme Court will uphold its decision which states that corporations have obligations not to infringe upon the human rights of others, and build upon its previous case law on this subject.

Two interesting developments can be observed from these cases, both of a horizontal and vertical nature: first, in Mexico, corporations have a legal responsibility to respect human rights within their business agreements, not just as a basic expectation of society, but as a matter of public policy; this implies that human rights are to be observed whenever a contract is concluded by two parties, regardless of the horizontal nature of the business relationship. Second, whenever a corporation impacts on human rights through its actions or omissions regardless of its private nature, it can be held responsible, in Mexico, for the human rights violation in addition to the state organ in charge of ensuring the protection of human rights.

\section{A WAY ForWARD?}

If the development of a domestic public policy on business and human rights in Mexico has been practically non-existent to date, cases resolved by the Supreme Court provide interesting examples of the progressive application of human rights standards to corporations. The development of case law on the horizontal application of human rights to corporate activities, as well as the establishment of a public policy exception based on the universality of human rights, directly contribute to the solidification of standards that are intrinsically compatible with the spirit of the UN GPs.

Despite this, it is important and necessary that Mexico develops a domestic agenda on business and human rights soon. Different constitutional and legal reforms that have been adopted or that are currently under discussion (such as the privatization of water under the proposed General Water Bill, the reform of the energy sector allowing participation of multinational corporations, and the openness of the ICT sector) may pose a direct threat to the protection of human rights, particularly if the government does not have clear guidelines on its obligations and methods of enforcement against private actors. Having a national action plan will not necessarily solve all the issues of this complex field, but may at least provide a baseline from which the state may act to comply with its international human rights obligations, and to ensure that corporations respect human rights. 